\title{
The Dynamic Game Analysis of the Civil Servant Corruption and Government Supervision
}

\author{
Nannan Shan \\ School of Hebei University of Science and Technology,Shijiazhuang,China \\ 1006026809@qq.com
}

Keywords: Corruption; Dynamic game; Costs; Expected returns; Nash Equilibrium

\begin{abstract}
In recent years, with the rapid development of network information,the ways of people contacting and paying attention to the political news are more much and available. The corruption has become a focus problem of the society,and numerous official corruption also frequently reported through the media.Considering the huge damage to the government and the society, the central government also pay more attention to the anti-corruption work, and promote anti-corruption.To the problem of civil servants corruption, this paper uses the method of dynamic game and analyses the two civil servants and government's costs and expected returns in the process of civil servants corruption,Nash equilibrium of the main benefit maximization. According to the basic conclusions, we put forward the policy suggestion of the prevention of corruption to echo government work better and purify officialdom atmosphere.
\end{abstract}

\section{Introduction}

Corruption is called "the government cancer".Corruption is an existent phenomenon accompanied by the existence of social development. The corruption of government official would not only make the public lose trust and confidence to government,but also cause public outrage and result in carrying out the work of the government difficultly. On the hand,corruption breeding will also affect the social and economic development to a certain extent. Some scholars have pointed out that corruption is the government's biggest tumor disease and only to second the harmfulness of tyranny. Throughout history, due to lack of supervision,right desires and other reasons, there is no time to avoid the corruption. For the government, corruption can reduce the administrative efficiency, public trust and the cost of the overrun; and for the society, it will disrupt the market order, damage to the principle of good faith, and increase the gap between rich and poor. Since the constitutional monarchy in Thailand, almost 3 years taking place a coup on average, it is one of the countries of the world's frequent coup. And each coup, the banner of the fight is eliminating corruption - politics becomes an extraordinary mean of eliminating corruption.In the present stage, we are very difficult to put an end to the phenomenon of corruption.But based on the serious harm of corruption,corruption prevention and control work also be imperative.General Secretary Xi Jinping has stressed in China eighteenth National Congress of the Communist Party,adhering to oppose corruption,maintain party clean and honest political nature.Combating corruption and promoting political integrity,is the party's consistent and vivid political position and a major political issue of great concern to the people.In recent years, with the rapid development of China's economy, the civil 
servants' corruption spread rapidly.Therefore, research on the problem of corruption also represents the general trend.

\section{The definition of cost and expected return}

Cost. In order to simplify the analysis, this paper analysis the cost mainly includes two parts[1], one is the cost of supervision, namely the direct costs of the implementation of government supervision of civil servants; two is the cost of risk,namely the corruption of civil servants once they are discovered to bear the loss.Corruption is a very risky behavior.From the perspective of Economics:every input is risky.Because the corruption behavior needs investment,the risk is also inevitably existent.Therefore,the most cost of corruption is from the latter,that is, it would bear the loss, once it was found.These losses mainly include legal punishment, loss of political economy,loss of the spirit.So the cost of corruption is mainly determined by two factors: the probability of being found and the loss when they are found.

Expected return. The so-called expected income refers to the benefits. For civil servants, expected return is directly the economic benefits,including on the take,civil servants' normal wage gains and in the bribery case,economic benefits; The government's Expected return refers that the government supervise and found that civil servants bribery and punish incomes.

\section{The establishment of game model}

The main body of the game includes two sides:civil servants and government.And the main body's space activity include two types. Officials have bribe-taking and not accepting bribes two choices.Accordingly the government can actualize supervision or oversight.In the model,normal income of civil servants is I which contains wages, welfare,insurance,etc.; $M$ is the additional revenue to bribery.If the bribery is found,the loss including penalties will be L1, and the probability of civil servant bribery is p.the government supervision cost is C. Dealing with civil servants bribery gains is $\mathrm{R}$. If no supervision, as civil servants bribery act,the government loss is L2. When there is no bribery, the government's loss is 0 . The probability of government supervision is q. So,when the civil servants take bribes and government supervises, the civil servants benefit is -L1, the government's is $\mathrm{R}-\mathrm{C}$; if there is no supervision ,the civil servants benefit is I+M,the government's is -L2.In the same way, when the civil servants don't take bribes and the government don't imply supervision,the civil servants benefit is I,the government's is 0,even if the government carry out supervision,the civil servants benefit is also I,and the benefit government is -C.Therefore,we can establish the following model[2]:

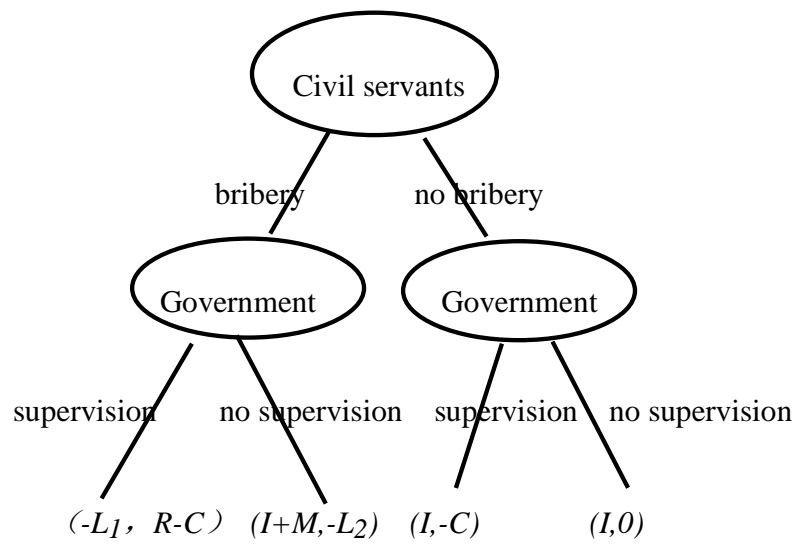

Note: $(\mathrm{a}, \mathrm{b})=($ civil servants' benefit, government's benefit $)$ 


\section{Dynamic game analysis of expected return}

Through the game tree of civil servants' corruption act,we can see that the benefits of civil servant is -L1,I and I+M. With the probability of benefits, the expected benefits of U1 for civil servants[3]:

$$
\begin{aligned}
\mathbf{U}_{1} & =(1-\mathbf{p}) \mathbf{q}^{*} \mathbf{I}+(1-\mathbf{p})(1-\mathrm{q}) * \mathbf{I}+\mathbf{p}(1-\mathbf{q})(\mathbf{I}+\mathbf{M})-\mathrm{p} * \mathrm{q} * \mathbf{L}_{1} \\
& =\mathbf{I}+\mathbf{p}\left[(1-\mathbf{q})(\mathbf{I}+\mathbf{M})-\mathbf{q} * \mathbf{L}_{1}-\mathbf{I}\right]
\end{aligned}
$$

Similarly, the government expected return U2:

$$
\begin{aligned}
\mathrm{U}_{2} & =-(1-\mathrm{p}) \mathrm{q} * \mathrm{C}+\mathrm{p} * \mathrm{q}(\mathrm{R}-\mathrm{C})-\mathrm{p}(1-\mathrm{q}) \mathrm{L}_{2} \\
& =\mathrm{q}\left[\mathrm{p}\left(\mathrm{R}+\mathrm{L}_{2}\right)-\mathrm{C}\right]-\mathrm{p} * \mathrm{~L}_{2}
\end{aligned}
$$

Mixed strategy Nash equilibrium for the game model to calculate the partial derivative of U1 on $\mathrm{p}$, and that partial derivative is equal to 0 , there is:

$$
\begin{aligned}
& \frac{\partial U_{1}}{\partial P}=(\mathbf{1}-\mathbf{q})(\mathbf{I}+\mathbf{M})-\mathrm{q} * \mathbf{L} \mathbf{1}-\mathbf{I}=\mathbf{O} \\
& \mathrm{q}=\frac{M}{I+M+L_{1}}
\end{aligned}
$$

When $\mathrm{q}=\frac{M}{I+M+L_{1}}, \frac{\partial U_{1}}{\partial P}=0$, civil servants' expected return depends on the supervision probability of government,as long as $\mathrm{q}=\frac{M}{I+M+L_{1}}$, the expected return of bribery and no bribery are no difference about civil servants, only when the supervision probability is less than $\frac{M}{I+M+L_{1}}$, civil servants will choose bribery.

Seeking the government expected return partial derivative on $\mathrm{q}$, then it is equal to 0 , there is:

$$
\begin{aligned}
& \frac{\partial U_{2}}{\partial \mathrm{q}}=\mathrm{p}\left(R+L_{2}\right)-C=0 \\
& \mathrm{p}=\frac{C}{R+L_{2}} \\
& \mathrm{p}=\frac{C}{R+L_{2}}, \quad \frac{\partial U_{2}}{\partial \mathrm{q}}=0
\end{aligned}
$$

,government's expected return depends on the probability of

civil servants' bribery. Only the probability of bribery $\mathrm{p}=\frac{C}{R+L_{2}}$, there is no difference between government supervision and no supervision of expected return .

Therefore, the only Nash Equilibrium[4] of the game model in this paper is, 


$$
(\mathrm{p}, \mathrm{q})=\left(\frac{C}{R+L_{2}}, \frac{M}{I+M+L_{1}}\right)
$$

\section{The basic conclusion}

By the Nash equilibrium solution that it was found relevant with the government's supervision costs $\mathrm{C}$,gains of $\mathrm{R}$, loss of L2, their normal income of civil servants I, additional revenue $\mathrm{M}$, and a loss was discovered L1 factors. On the one hand, with the higher supervision cost of government $\mathrm{C}$,smaller income $\mathrm{R}$ or smaller $\mathrm{L} 2$, the government will be reluctant to supervise, but bribery probability $\mathrm{p}$ will rise of civil servants. On the other hand, when civil servants accept bribes, the additional return $\mathrm{M}$ is greater or normal income less $\mathrm{I}$, the civil servants will tend to choose to accept bribes, and government supervision probability q will rise, but if you choose bribery, losses L1 after being found is large, the civil servants will not be willing to choose to accept bribes, correspondingly the government supervision probability q will fall.

\section{Policy Suggestion}

From the conclusions, the inner relation between the main reason for bribery and their maximum interests can be found. Finally some targeted countermeasures of civil servants corruption prevention and treatment are put forward..

The prosecutor of local prosecutor's office eastern branch in Seoul, South Korea,Ju Benmin thinks: for the crime, before the prevention is the highest strategy[5]. So the prevention of corruption in civil servants, the first is to establish the ethical justifications, generate specific job responsibilities and rights criteria of civil servants, and with the disciplinary measures. Civil servant is as the role of waiter to citizens.It should set up the mental state, and be clear to their responsibility and mission, in order to get public trust and respect. Therefore, countries should guarantee reasonable wages of civil servants, to put forward strict requirements to civil servants. From the importance of the civil servants' career and the characteristics of human capital's higher levels, civil servants' pay levels should be at the forefront of the society is to guarantee the external equity.We can't say that high salary guarantees the honesty, but at least it can reduce corruption.

In addition, in our country, the civil servant salary are divided into three parts: basic salary, allowances, bonuses, "The basic salary of post wage and salary grade is too small, for only $30 \%$, other $60 \%$ more is for subsidies and allowances, which theoretically, history and the comparison of foreign civil servant salary structure is not reasonable at all." the Chinese society of labor remuneration professional committee chairman Su Haina emphasized when he was interviewed by the China Times[6]. Recently the State Department approved the National Development and Reform Commission about " Comments on key work of deepening economic restructuring in 2015", which clearly put forward that" perfecting the staff salary system in government institutions ", etc; in this reform, the proportion of institutions and civil servants' salaries will be "one gain one minus", namely reducing allowances and increasing base salaries. In fact,civil servant's real income is higher than that of similar enterprise personnel, also many are lower than the similar's, especially the grass-roots level.So that, it's necessary to deepen the reform of the civil servant salary system and further clean up the subsidies of civil servants, standard welfare and salary distribution, and pay 
special attention to the related reform at the same time.Then it may be able to make the wages of civil servants at a reasonable level.

For the management of civil servant's corruption, the government need to do"zero tolerance to corruption"[7].The"zero tolerance" claim against corruption is a kind of "political cleanliness", given the strong concealment of corruption, it is reasonable but it is not reality. But to the corruption that has been found, it should be given the economic punishment and legal punishment. Some scholars in the perspective of human nature hypothesis and ethics think that right is the necessary but non-sufficient conditions for the corruption of civil servants, corruption or not vary from person to person.Also some scholars believe that the basis of corruption government is the rigid law rein, and they advocate that using severe criminal law intensifies punished for corruption[8]. The author thinks that it can't purely follow the human nature assumption, but also consider the economic rationality of civil servants; only when the expected return is less than expected cost of corruption, corruption is not easy to happen. So it must increase the risk of corruption and cost to achieve the goal of curbing corruption.

Reduce government supervision cost can also reduce the probability of civil servants bribery. So organically combined the public supervision and government supervision to form a supervision network with a diversity of main body and mutual coordination, and set up the public telephone and email, give full play to the role of all kinds of mass media and the Internet. By the successful experience of foreign anti-corruption, the network anti-corruption even can do the things that the minister can't do[9]. Difference with the China's anti-corruption website led by government, in a foreign country,the folk anti-corruption website is most popular. Through the website, ordinary people can be large inverted grievances, expose official greedy. A Russian lawyer and blogger launched a personal website named RosPil dedicated to expose official corruption, wantonly pursued by people. Since RosPil online, by 2011, the bidding projects which were canceled due to be disclosed worth $\$ 6.6$ million. When the site's founder announced for RosPil website sponsorship, in just over a week time, it raised $\$ 120000$,.it is not easy in popular cynicism Russia. And the scandal of corrupt officials as the media or network exposure, they will be severely condemned by the public, falling into disrepute, or even is sued.

\section{References}

[1] Wang Jian. Economic Analysis of servant Corruption and Governance [D]. Chongqing University, 2008

[2] Cai Derong, Li Lang. Corruption and Anti-Corruption Game economic analysis [J] study Financial and Economic Issues, 10 (2010): 21-25.

[3] Cai Shanshan .comparative analysis of civil servants corruption costs and benefits [J]. Tianshui College of Administration, 2013,3

[4] Zhang Xiaoying, Nan Guojun. Game Analysis and Governance in misconduct research area[J] Xiamen University, 6(2011): 135-140.

[5] Daomin $\mathrm{Xu}$,The basic trajectory of anti-corruption cure corruption in Korea[J].Supervision China,19(2002)

[6] Information on http://big5.askci.com/edu/2015/05/25/94113myb1.shtml 
[7] Yanling Li, Wu Songjiang, Hu Yangming. the summary of anti-corruption problem in recent years[D] Chinese administration,11(2011): 115-119.

[8] Meng Wenjing. Based on the cost analysis of corruption and governance [D]. Shandong University, 2012

[9] Weijia Wang.See how foreign anti-corruption[J].World Vision,11(2011):59-60 